\title{
The Effects of Barley-Derived Soluble Fiber on Serum Lipids
}

\author{
Ripple Talati, PharmD ${ }^{1,2}$ \\ William L. Baker, PharmD, BCPS 1,2 \\ Mary S. Pabilonia, PharmD ${ }^{1}$ \\ C. Michael White, PharmD, FCP, \\ FCCP ${ }^{1,2}$ \\ Craig I. Coleman, PharmD ${ }^{1,2}$ \\ 'University of Connecticut School \\ of Pharmacy, Storrs, Connecticut \\ ${ }^{2}$ Department of Drug Information at \\ Hartford Hospital, Hartford, Connecticut
}

\begin{abstract}
PURPOSE We wanted to determine the association between consumption of barley and changes in plasma lipids in healthy and hypercholesterolemic men and women.

METHODS A systematic literature search was conducted from the earliest possible date through January 2008. Trials were included in the analysis if they were randomized controlled trials of barley that reported efficacy data on at least 1 lipid endpoint. A DerSimonian and Laird random-effects model was used in calculating the weighted mean difference (WMD) and its 95\% confidence interval (CI). Statistical heterogeneity was addressed using the $I^{2}$ statistic. Visual inspection of funnel plots, Egger's weighted regression statistics, and the trim and fill method were used to assess for publication bias.
\end{abstract}

RESULTS We found 8 trials ( $\mathrm{n}=391$ patients) of 4 to 12 weeks' duration evaluating the lipid-reducing effects of barley. The use of barley significantly lowered total cholesterol (weighted mean difference [WMD], $-13.38 \mathrm{mg} / \mathrm{dL} ; 95 \% \mathrm{Cl}$, -18.46 to $-8.31 \mathrm{mg} / \mathrm{dL}$ ), low-density lipoprotein (LDL) cholesterol (WMD, -10.02 $\mathrm{mg} / \mathrm{dL} ; 95 \% \mathrm{Cl},-14.03$ to $-6.00 \mathrm{mg} / \mathrm{dL}$ ) and triglycerides (WMD, $-11.83 \mathrm{mg} / \mathrm{dL}_{\text {; }}$ $95 \% \mathrm{Cl},-20.12$ to $-3.55 \mathrm{mg} / \mathrm{dL}$ ) but did not appear to significantly alter highdensity lipoprotein ( $\mathrm{HDL})$ cholesterol $(P=.07)$.

CONCLUSION Barley-derived $\beta$-glucan appears to beneficially affect total cholesterol, LDL-cholesterol, and triglycerides, but not HDL-cholesterol.

Ann Fam Med 2009;7:157-163. DOI: 10.1370/afm.917.

\section{INTRODUCTION}

ccording to the guidelines of the National Cholesterol Education
Program (NCEP), approximately $30 \%$ of Americans have undesir-
ably high serum cholesterol concentrations. ${ }^{1}$ High serum lipid levels, including total cholesterol, low-density lipoprotein (LDL) cholesterol, and triglycerides, are a major cause of coronary atherosclerosis. ${ }^{1}$ Any LDL cholesterol concentration above $100 \mathrm{mg} / \mathrm{dL}$ appears to be atherogenic and the higher the level, the greater the risk. ${ }^{1}$ Although elevated LDL cholesterol plays a role in the development of the coronary plaque instability, lowering LDL cholesterol stabilizes plaques and reduces the likelihood of acute coronary syndromes. ${ }^{1}$ Lowering serum cholesterol reduces the risk of coronary heart disease.

The effect of dietary fiber on cholesterol metabolism has been studied extensively. ${ }^{2,3}$ Barley and oats have a similar concentration of soluble fibers called $\beta$-glucan (3.5\%-5.9\% of the dry matter), whereas wheat and rice do not posses this constituent type of fiber. ${ }^{4}$ Unlike wheat and rice, ${ }^{5-10}$ a diet high in $\beta$-glucan has been shown to slow gastric emptying, digestion, and absorption. ${ }^{11}$ These effects are associated with increased excretion of bile acids and neutral sterols, increased catabolism of cholesterol, and reduced absorption of cholesterol and fat. ${ }^{12,13}$

Although the antihyperlipidemic effects of oats have been extensively studied, there are fewer barley studies, and findings have shown more 
apparent inconsistency in cholesterol effects. ${ }^{14,15}$ Some reasons for inconsistencies in the barley studies may be explained by differences in the $\beta$-glucan dose, the molecular size of $\beta$-glucan, the composition of dietary food, the process of food preparation, and the initial variation in cholesterol level. Even though several clinical trials ${ }^{10,16-29}$ have investigated the impact of barley $\beta$-glucan on total cholesterol, LDL cholesterol, highdensity lipoprotein (HDL) cholesterol, and triglycerides, a meta-analysis assessing these effects has not been published. We therefore sought to perform a meta-analysis of randomized controlled trials of barley to better characterize its effect on various lipid parameters.

\section{METHODS}

Was conducted a systematic literature search of MEDLINE, EMBASE, CINAHL, Web of Science, the Cochrane Library, and the Natural Medicines Comprehensive Database from the earliest possible date through January 2008. Our search strategy used the Medical Subject Headings (MeSH) and text key words: " $\beta$-glucan," "barley" and "lipids," "serum cholesterol," "total cholesterol," "low-density lipoproteins," "high-density lipoproteins," "LDL," "HDL," "triglycerides," or "hypercholesterolemia." This search was then limited to clinical trials in humans. We also performed a manual search of references from retrieved articles. When applicable, we made an effort to contact investigators for clarification or additional data (although no additional data were acquired).

To be included in this meta-analysis, studies had to be randomized controlled trials of barley and report data on at least 1 of the following lipid parameters: total cholesterol, LDL cholesterol, HDL cholesterol, or triglycerides. Both parallel and crossover trials were eligible for inclusion; however, crossover trials had to have at least a 4 week washout period. If this criterion was not met, when possible, we included only the first phase of each crossover trial.

A more detailed description of the methods can be found in the Supplemental Appendix, available online at http://www.

annfammed.org/cgi/content/full/ 7/2/157/DC1.

We treated the mean change in lipid parameters from baseline as a continuous variable, and the weighted mean difference (WMD) and its 95\% confidence interval (CI) were calculated as the difference between the mean in the $\beta$-glucan and control groups using a DerSimonian and Laird random-effects model ${ }^{30}$ For parallel trials, we calculated net changes in each of these study parameters as the difference ( $\beta$-glucan minus control) of the changes (baseline minus follow-up) in the mean values (also referred to as the change score). For crossover trials, we calculated net changes as the mean difference in values at the end of the $\beta$-glucan and control periods. Standard statistical methods were used to impute change scores, as suggested by Follman and colleagues. ${ }^{31}$

Statistical heterogeneity was addressed using the $I^{2}$ statistic. Visual inspection of funnel plots, Egger's weighted regression statistics, and the trim and fill method was used to assess for the presence of publication bias. ${ }^{32}$ Sensitivity analysis was conducted to assess the impact of double-blinding, the use of crossover methodology, and the use of a fixed-effects model (Mantel-Haenszel methodology). ${ }^{33}$ Additionally, subgroup analyses were conducted to assess the effect of using or not using concurrent dietary modifications and to asses the effect on only hypercholesterolemic patients. Statistics were performed using StatsDirect statistical software, version 2.4.6 (StatsDirect Ltd, Cheshire, England). A $P$ value of $<.05$ was considered statistically significant for all analyses.

\section{RESULTS}

The initial search yielded a total of 22 studies for fulltext review. For reasons depicted in Figure 1, 14 of

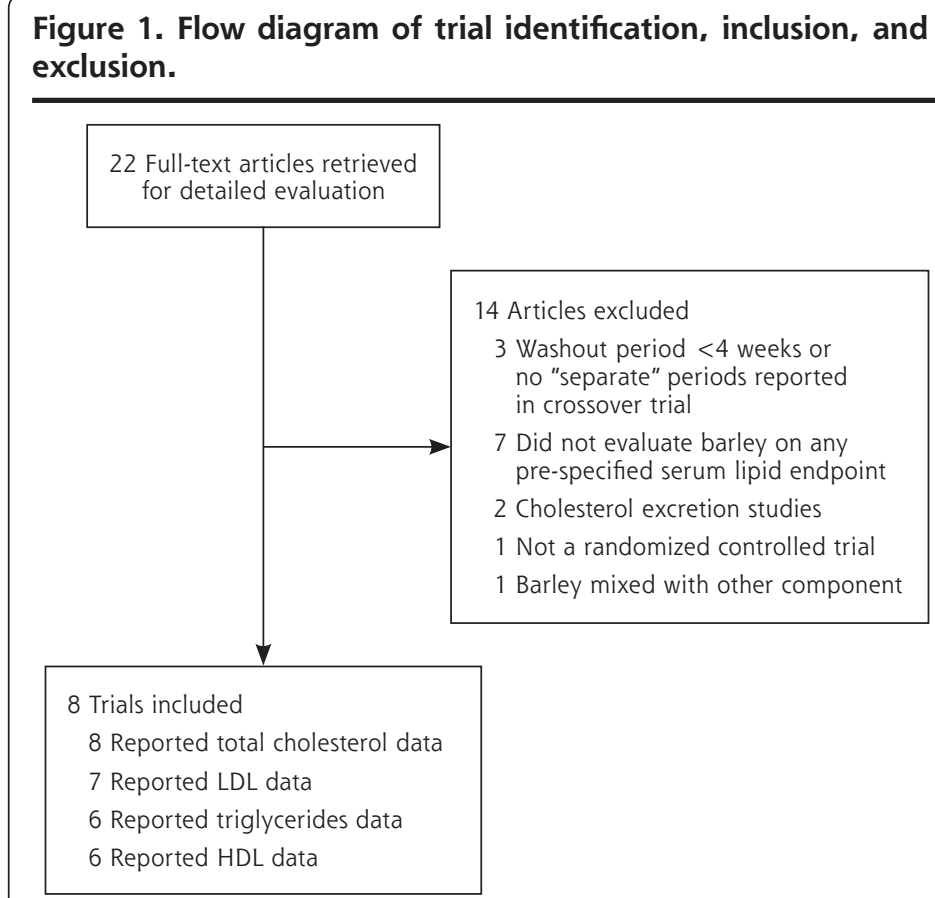

$\mathrm{HDL}=$ high-density lipoprotein cholesterol; $\mathrm{LDL}=$ low-density lipoprotein 
the 22 studies were excluded; therefore, a total of 8 randomized controlled trials ${ }^{10,16-22}$ (evaluating 391 participants) were included in this meta-analysis (Table 1). Five of the studies ${ }^{10,16-18,20}$ were conducted using a parallel study design, whereas 2 studies $^{19,22}$ used a crossover design with a 4 -week washout period, and 1 study $^{21}$ used a crossover design with no washout period and was treated as a parallel trial by taking into account only the first phase of the study data.

Each study enrolled relatively few participants (median sample size, 30 participants; range, 10-155 participants) and had a short duration of treatment (median duration, 4 weeks; range, 4-12 weeks). The dosage of $\beta$-glucan reported in included studies ranged from 3 to $10 \mathrm{~g} / \mathrm{d}$ (median dose, $7 \mathrm{~g} / \mathrm{d}$ ) and was administered in various forms, including pearled barley, barley bran flour, oil extracts in capsules, barley concentrates, barley-containing beverages, and gelling agents. Only 2 studies $^{17,20}$ administered barley along with some type of dietary modification. Of the 8 studies, 6 were not double-blind. ${ }^{10,18-22}$ Three of the 8 studies were industry funded. ${ }^{16,17,22}$

Upon meta-analysis, participants consuming barley had significantly greater reductions in total cholesterol, LDL cholesterol, and triglycerides, but not HDL cholesterol compared with control participants (Table 2, Figure 2). No statistical heterogeneity was observed in any of these analyses $\left(I^{2}=0 \%\right.$ for all). Visual inspec- tion of funnel plots (not shown) suggested a low likelihood of publication bias. This finding was further supported by Egger's weighted regression statistic $P$ values, which also suggested that publication bias was unlikely for all analyses except total cholesterol $(P=.02)$. After recalculating effect size estimates using trim and fill methods, barley's effect was not significantly altered for triglycerides. For total cholesterol, LDL cholesterol, and HDL cholesterol, the trim and fill analysis suggests that as many as 4 studies for total cholesterol and 3 studies for LDL cholesterol and HDL cholesterol could potentially exist for each endpoint; however, barley still had a significant, although reduced, effect when these theoretically "missing" studies were imputed for total cholesterol and LDL cholesterol. For HDL cholesterol, the original analysis did not show significance, but after imputing the 3 "missing" studies from the trim and fill, it was statistically significant for this endpoint.

Upon subgroup and sensitivity analysis, similar results were seen for all of the study endpoints when crossover or non-double-blinded studies were excluded, except the effect of barley on triglycerides lost statistical significance (Table 2). When a fixedeffects model was used, the results did not change. When studies evaluating barley in only hypercholesterolemic patients were analyzed, the effect of barley on triglycerides lost statistical significance but still

Table 1. Characteristics of Included Randomized Controlled Trials of Barley

\begin{tabular}{|c|c|c|c|c|c|c|c|c|}
\hline Reference & Design & $\begin{array}{l}\text { Type of } \\
\text { Patient }\end{array}$ & $\begin{array}{l}\text { Double- } \\
\text { Blinding }\end{array}$ & $\mathbf{N}^{a}$ & $\begin{array}{l}\text { Duration of } \\
\text { Treatment } \\
\text { (wk) }\end{array}$ & $\begin{array}{l}\text { Preparation } \\
\text { of Barley }\end{array}$ & $\begin{array}{l}\text { B-Glucan } \\
\text { Intake } \\
\text { per Day }\end{array}$ & $\begin{array}{l}\text { Concurrent } \\
\text { Diet } \\
\text { Modification }\end{array}$ \\
\hline $\begin{array}{l}\text { Shimizu et al, }{ }^{16} \\
2007\end{array}$ & Parallel & $\begin{array}{c}\text { Hyper- } \\
\text { cholesterolemic }\end{array}$ & Yes & 39 & 12 & Pearled barley & $7 \mathrm{~g}$ & None \\
\hline $\begin{array}{l}\text { Keenan et al, }{ }^{17} \\
2007\end{array}$ & Parallel & $\begin{array}{c}\text { Hyper- } \\
\text { cholesterolemic }\end{array}$ & Yes & 155 & 6 & $\begin{array}{l}\text { Barley concentrate } \\
\text { in cereal and } \\
\text { juice }\end{array}$ & $\begin{array}{l}3 \text { or } 5 \mathrm{~g} \text { of } \\
\text { either } \\
\text { HMW or } \\
\text { LMW }\end{array}$ & $\begin{array}{l}\text { Low saturated } \\
(<10 \%) \text { \& low } \\
\text { trans unsatu- } \\
\text { rated fat diet }\end{array}$ \\
\hline $\begin{array}{l}\text { Biörklund et al, }{ }^{18} \\
2005\end{array}$ & Parallel & $\begin{array}{l}\text { Hyper- } \\
\text { cholesterolemic }\end{array}$ & No & 55 & 5 & $\begin{array}{l}\text { Barley concentrate } \\
\text { as beverage }\end{array}$ & 5 or $10 \mathrm{~g}$ & None \\
\hline $\begin{array}{l}\text { Keogh et al, }{ }^{19} \\
2003\end{array}$ & Crossover & $\begin{array}{c}\text { Hyper- } \\
\text { cholesterolemic }\end{array}$ & No & 18 & 4 & $\begin{array}{l}\text { Naturally extracted } \\
\text { barley } \beta \text {-glucan } \\
\text { as a gel }\end{array}$ & $9.9 \mathrm{~g}$ & None \\
\hline Li et al, 222003 & Crossover & Healthy & No & 10 & 4 & $\begin{array}{l}\text { Barley bran in } \\
\text { whole grain }\end{array}$ & NR & None \\
\hline $\begin{array}{l}\text { Lupton et al, }{ }^{20} \\
\quad 1994\end{array}$ & Parallel & $\begin{array}{c}\text { Hyper- } \\
\text { cholesterolemic }\end{array}$ & No & 79 & 4 & $\begin{array}{l}\text { Barley bran flour } \\
\text { or oil extract in } \\
\text { capsules }\end{array}$ & NR & Step I diet \\
\hline $\begin{array}{l}\text { Mclntosh et al, }{ }_{1}^{21} \\
1991\end{array}$ & Parallel $^{b}$ & $\begin{array}{l}\text { Hyper- } \\
\text { cholesterolemic }\end{array}$ & No & 21 & 4 & $\begin{array}{l}\text { Barley grain (bran } \\
\text { and flakes) }\end{array}$ & $8 \mathrm{~g}$ & None \\
\hline $\begin{array}{l}\text { Newman et al, }{ }^{10} \\
1989\end{array}$ & Parallel & Healthy & No & 14 & 4 & $\begin{array}{l}\text { Barley grain flour } \\
\text { in cereal and } \\
\text { baked goods }\end{array}$ & $4.5 \mathrm{~g}$ & None \\
\hline \multicolumn{9}{|c|}{$\begin{array}{l}\mathrm{HMW} \text { or LMW }=\text { high or low molecular weight } \beta \text {-glucan; NR }=\text { not reported; step I diet }=\text { diet consisting total fat to } \leq 30 \% \text { of total calories, saturated fat to } \leq 10 \% \text { of } \\
\text { total calories, and cholesterol to } 300 \mathrm{mg} / \mathrm{d} \text {. }\end{array}$} \\
\hline
\end{tabular}




\begin{tabular}{|c|c|c|c|c|}
\hline Study Type & $\begin{array}{l}\text { Total Cholesterol } \\
\mathrm{mg} / \mathrm{dL}(95 \% \mathrm{CI})\end{array}$ & $\begin{array}{l}\text { LDL Cholesterol } \\
\mathrm{mg} / \mathrm{dL}(95 \% \mathrm{Cl})\end{array}$ & $\begin{array}{l}\text { HDL Cholesterol } \\
\text { mg/dL (95\% Cl) }\end{array}$ & $\begin{array}{l}\text { Triglycerides } \\
\text { mgldL }(95 \% \mathrm{Cl})\end{array}$ \\
\hline All studies & $\begin{array}{c}-13.38 \\
(-18.46 \text { to }-8.31) \\
\text { [8 studies }]\end{array}$ & $\begin{array}{c}-10.02 \\
(-14.03 \text { to }-6.00) \\
{[7 \text { studies }]}\end{array}$ & $\begin{array}{c}0.99 \\
(-0.09 \text { to } 2.06) \\
\text { [6 studies] }\end{array}$ & $\begin{array}{c}-11.83 \\
(-20.12 \text { to }-3.55) \\
{[6 \text { studies }]}\end{array}$ \\
\hline Fixed-effects model & $\begin{array}{c}-13.38 \\
(-18.46 \text { to }-8.31) \\
{[8 \text { studies }]}\end{array}$ & $\begin{array}{c}-10.02 \\
(-14.03 \text { to }-6.00) \\
{[7 \text { studies }]}\end{array}$ & $\begin{array}{c}0.99 \\
\text { (-0.09 to } 2.06) \\
\text { [6 studies] }\end{array}$ & $\begin{array}{c}-11.83 \\
(-20.12 \text { to }-3.55) \\
{[6 \text { studies }]}\end{array}$ \\
\hline Excluding crossover studies & $\begin{array}{c}-13.75 \\
(-19.24 \text { to }-8.26) \\
{[6 \text { studies }]}\end{array}$ & $\begin{array}{c}-9.76 \\
(-14.64 \text { to }-4.88) \\
{[5 \text { studies }]}\end{array}$ & $\begin{array}{c}-0.97 \\
(-3.31 \text { to } 1.36) \\
\text { [4 studies] }\end{array}$ & $\begin{array}{c}-13.68 \\
(-12.74 .0 .39) \\
{[4 \text { studies }]}\end{array}$ \\
\hline Excluding studies not double-blind & $\begin{array}{c}-17.39 \\
(-26.05 \text { to }-8.74) \\
{[2 \text { studies }]}\end{array}$ & $\begin{array}{c}-13.43 \\
(-20.58 \text { to }-6.29) \\
{[2 \text { studies }]}\end{array}$ & $\begin{array}{c}0.85 \\
\text { (-4.71 to } 6.41) \\
\text { [1 studies] }\end{array}$ & $\begin{array}{c}-22.45 \\
(-50.65 \text { to } 5.76) \\
\text { [1 studies }]\end{array}$ \\
\hline $\begin{array}{l}\text { Excluding studies in patients } \\
\text { without hypercholesterolemia }\end{array}$ & $\begin{array}{c}-12.56 \\
(-17.89 \text { to }-7.24) \\
\text { [6 studies }]\end{array}$ & $\begin{array}{c}-9.38 \\
(-14.13 \text { to }-4.63) \\
{[5 \text { studies }]}\end{array}$ & $\begin{array}{c}1.08 \\
\text { (-0.01 to } 2.17) \\
\text { [4 studies] }\end{array}$ & $\begin{array}{c}-11.06 \\
(-24.97 \text { to } 2.85) \\
{[4 \text { studies }]}\end{array}$ \\
\hline Trim and fill & $\begin{array}{c}-10.49 \\
(-15.09 \text { to }-5.89) \\
{[+4 \text { studies }]}\end{array}$ & $\begin{array}{c}-8.45 \\
(-12.21 \text { to }-4.69) \\
{[+3 \text { studies }]}\end{array}$ & $\begin{array}{c}1.34 \\
(0.31 \text { to } 2.37) \\
{[+3 \text { studies }]}\end{array}$ & $\begin{array}{c}-11.83 \\
(-20.12 \text { to }-3.55) \\
{[+0 \text { studies }]}\end{array}$ \\
\hline $\begin{array}{l}\text { Studies evaluating barley } \\
\text { with diet modification }\end{array}$ & $\begin{array}{c}-17.14 \\
(-25.02 \text { to }-9.23) \\
{[2 \text { studies }]}\end{array}$ & $\begin{array}{c}-14.57 \\
(-21.69 \text { to }-17.45) \\
{[2 \text { studies }]}\end{array}$ & $\begin{array}{c}1.53 \\
\text { (-2.98 to } 6.05) \\
\text { [2 studies] }\end{array}$ & $\begin{array}{c}-17.36 \\
(-40.66 \text { to } 5.94) \\
\text { [2 studies }]\end{array}$ \\
\hline $\begin{array}{l}\text { Studies evaluating barley } \\
\text { without diet modification }\end{array}$ & $\begin{array}{c}-10.75 \\
(-17.38 \text { to }-4.12) \\
\text { [6 studies }]\end{array}$ & $\begin{array}{c}-7.89 \\
(-12.75 \text { to }-3.04) \\
{[5 \text { studies }]}\end{array}$ & $\begin{array}{c}-0.16 \\
(-2.33 \text { to } 2.02) \\
\text { [4 studies] }\end{array}$ & $\begin{array}{c}-11.03 \\
(-19.90 \text { to }-2.17) \\
\text { [4 studies }]\end{array}$ \\
\hline
\end{tabular}

trended toward a reduction. When studies using and not using dietary modification were assessed separately, the effect of barley on serum lipids qualitatively appeared more robust when combined with dietary modifications.

\section{DISCUSSION}

In our meta-analysis of 8 randomized controlled trials, participants receiving barley had statistically significant reductions in total cholesterol $(-13 \mathrm{mg} / \mathrm{dL}), \mathrm{LDL}$ cholesterol $(-10 \mathrm{mg} / \mathrm{dL})$, and triglycerides $(-12 \mathrm{mg} / \mathrm{dL})$ compared with control group participants. Because studies have shown that for each milligram per deciliter reduction in a patient's LDL cholesterol level, their relative risk of having a coronary heart disease event is decreased by $1 \%$, this modest reduction in LDL cholesterol observed with barley is likely clinically significant as well. ${ }^{34}$

This reduction in total cholesterol and LDL cholesterol is in line with that found for oat-derived $\beta$-glucan. In a meta-analysis of oats containing 2 to $10 \mathrm{~g} / \mathrm{d}$ of $\beta$ glucan, there was a net change resulting from soluble fiber ingested of $-3.1 \mathrm{mg} / \mathrm{dL}$ to $-15.5 \mathrm{mg} / \mathrm{dL}$ for total cholesterol, and $-2.9 \mathrm{mg} / \mathrm{dL}$ to $-14.3 \mathrm{mg} / \mathrm{dL}$ for LDL cholesterol. ${ }^{35}$ Barley and oats have similar concentrations of $\beta$-glucans (3.5\%-5.9\% of the dry matter), the proposed active ingredient in both soluble fibers, so a similar magnitude of total cholesterol or LDL cholesterol reductions is plausible. ${ }^{4}$ In the meta-analysis of oats by Brown and colleagues, however, changes of -0.08 to $0.4 \mathrm{mg} / \mathrm{dL}$ were noted for HDL cholesterol, and changes of 1.06 to $5.3 \mathrm{mg} / \mathrm{dL}$ were noted for triglycerides, which is in contrast to our meta-analysis, in which with barleyderived $\beta$-glucan we saw a nonsignificant increase of 1 $\mathrm{mg} / \mathrm{dL}$ for HDL cholesterol and a significant reduction of $12 \mathrm{mg} / \mathrm{dL}$ in triglycerides compared with a control group. ${ }^{35}$ In addition, Brown and colleagues found a dose-response relationship when evaluating studies of soluble fibers in the practical dose range $(<10 \mathrm{~g} / \mathrm{d}) .^{35}$ That review, however, included 67 clinical trials evaluating a variety of soluble fibers (not including barley). Thus, their analysis was appropriately powered to evaluate dose response. In comparison, our meta-analysis included 8 studies, only 6 of which reported a $\beta$-glucan dose ( $75 \%$ of total patient population), making it difficult to conduct a dose-response analysis. At least 10 studies are recommended to provide adequate power. ${ }^{36}$

The Food and Drug Administration (FDA) has stated that daily intakes of $3 \mathrm{~g}$ or more of soluble fiber 


\section{Figure 2. Impact of barley on serum lipids.}

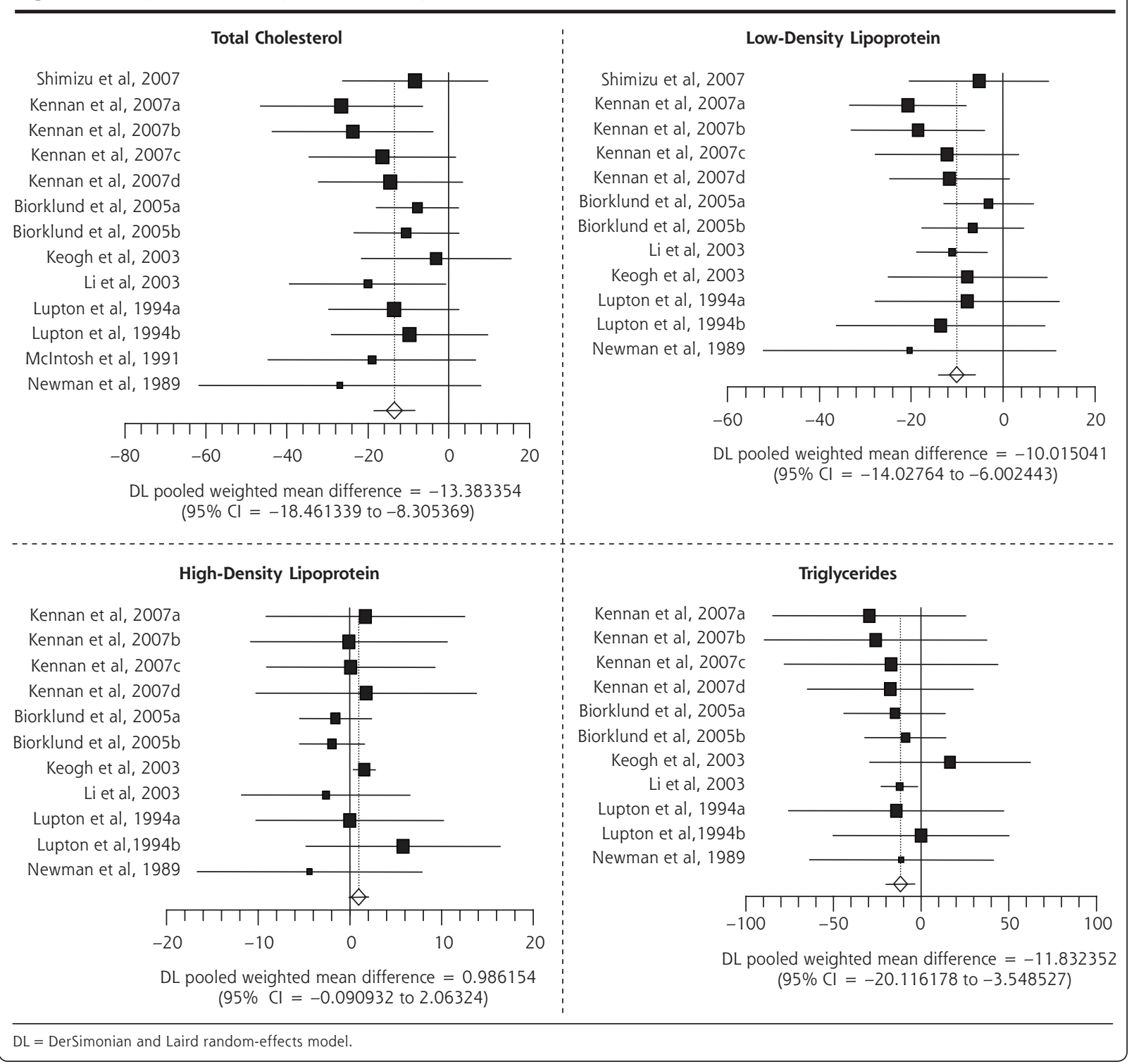

( $\beta$-glucan) in whole oats or barley may reduce the risk of heart disease by its ability to lower total cholesterol and LDL cholesterol. ${ }^{37,38}$ Our meta-analysis results support this FDA decision, because 3 to $10 \mathrm{~g}$ of $\beta$-glucan from various forms of barley lowered total cholesterol, LDL cholesterol, and triglycerides in the study participants. Furthermore, a significant reduction in total cholesterol and LDL cholesterol was found regardless of whether a low-fat or step I diet was mandated equally in both arms of the studies. This finding is important because of the potential for a dietary substitution effect. If study participants are replacing their normal foods (eg, eggs, bacon, sausage) with barley, it may be difficult to discern whether the improvements in cholesterol resulted from the healthier diet or from barley.
That significant reductions in total cholesterol and LDL cholesterol were seen regardless of whether diet modifications were mandated equally in both study groups helps guard against the issue of dietary substitution and strengthens the beneficial effects of barley use.

There are some limitations to this meta-analysis that should be noted. First, we included crossover and parallel studies. Crossover studies have methodological advantages compared with parallel studies, because patients act as their own controls; however, an adequate washout period is necessary. As such, we did not include trials that did not explicitly state the presence and duration of the washout period or trials that had a washout period of fewer than 4 weeks, in which case, we only included the first phase of the 
study when possible. The only noteworthy change seen upon conducting a sensitivity analysis excluding crossover studies was loss of statistical significance in the triglycerides endpoint.

Second, as with any meta-analysis, the potential for publication bias is a concern. Although visual inspection of our meta-analysis' funnel plot could not rule out the possibility of publication bias, review of Egger's weighted regression statistics and trim and fill analyses showed that it was unlikely that publication bias significantly affected our study results. Finally, we did not evaluate the potential for harms with barley. Based upon available data, barley appears to be well tolerated, with flatulence and abdominal discomfort being reported as the most common adverse effects, but there is not adequate power to look for other less common adverse effects. ${ }^{17}$

The results of our study support the routine use of soluble fibers in the diets of adult patients with and without hypercholesterolemia. Barley adds another source of soluble fibers, in addition to oats, psyllium, pectin, and guar gum that patients can consume as part of a healthy diet. ${ }^{35}$ Larger randomized clinical trials are warranted to better characterize the potential for a dose-response relationship with barley $\beta$-glucan. Health practitioners should feel comfortable recommending barley $\beta$-glucan to their patients to help reduce total cholesterol and LDL cholesterol concentrations as recommended by the NCEP guidelines. ${ }^{1}$

To read or post commentaries in response to this article, see it online at http://www.annfammed.org/cgi/content/full/7/2/157.

Submitted March 28, 2008; submitted, revised, July 15, 2008; accepted July 30, 2008.

Key words: Barley; beta-glucans; dietary fiber; lipids; meta-analysis

\section{References}

1. National Cholesterol Education Program (NCEP). Third Report of the NCEP Expert Panel on Detection, Evaluation and Treatment of High Blood Cholesterol in Adults (Adult Treatment Panel III). National Heart Lung and Blood Institute; 2002:1-284.

2. Anderson JW, Tietyen-Clark J. Dietary fiber: hyperlipidemia, hypertension and coronary heart disease. Am J Gastroenterol. 1986;81 (10):907-919.

3. Kritchevsky D. Dietary fiber and lipid metabolism. Int J Obes. 1987;11(Suppl. 1):S33-S43.

4. Oscarsson M, Andersson R, Aman P, et al. Effects of cultivar, nitrogen fertilization rate and environment on yield and grain quality of barley. J Sci Food Agric. 1998;78:359-366.

5. Van Horn LV, Liu K, Parker D, et al. Serum lipid response to oat product intake with a fat-modified diet. J Am Diet Assoc. 1986; 86(6):759-764.

6. Gold KV, Davidson DM. Oat bran as a cholesterol-reducing dietary adjunct in a young, healthy population. West J Med. 1988;148(3):299-302.
7. Anderson JW, Story L, Sieling B, et al. Hypocholesterolemic effect of oat-bran or bean intake for hypercholesterolemic men. Am J Clin Nutr. 1984;40(6):1146-1155.

8. Prentice N, Qureshi AA, Burger WC, Elson CE. Response of hepatic cholesterol, fatty acid synthesis and activities of related enzymes to rolled barley and oats in chickens. Nutr Rep Int. 1982;26(4):597-604.

9. Qureshi AA, Burger WC, Elson CE, Benevenga NJ. Effects of cereals and culture filtrate of Trichoderma viride on lipid metabolism of swine. Lipids. 1982;17(12):924-934.

10. Newman RK, Lewis SE, Newman CW, Boik RJ. Hypocholesterolemic effect of barley foods on healthy man. Nutr Rep Int. 1989;39:749-760.

11. Schneeman BO. Dietary fiber and gastrointestinal function. Nutr Res. 1998;18(4):625-632.

12. Lia A, Hallmans G, Sandberg AS, et al. Oat beta-glucan increases bile acid excretion and a fiber-rich barley fraction increases cholesterol excretion in ileostomy subjects. Am J Clin Nutr. 1995;62(6):1245-1251.

13. Marlett JA. Sites and mechanism for the hypocholesterolemic actions of soluble dietary fiber sources. Adv Exp Med Biol. 1997;427:109-121.

14. Kim SY, Song HJ, Lee YY, et al. Biomedical issues of dietary fiber $\beta$-glucan. J Korean Med Sci. 2006;21(5):781-789.

15. Wood PJ. Cereal $\beta$-glucans in diet and health. J Cereal Sci. 2007; 46:230-238.

16. Shimizu C, Kihara M, Aoe $S$, et al. Effect of high $\beta$-glucan barley on serum cholesterol concentrations and visceral fat area in Japanese men-a randomized, double-blinded, placebo-controlled trial. Plant Foods Hum Nutr. 2008;63(1):21-25. Epub 2007 Dec 12.

17. Keenan JM, Goulson M, Shamliyan T, et al. The effects of concentrated barley $\beta$-glucan on blood lipids in a population of hypercholesterolaemic men and women. Br J Nutr. 2007;97(6):1162-1168.

18. Biörklund M, van Rees A, Mensink RP, Onning G. Changes in serum lipids and postprandial glucose and insulin concentrations after consumption of beverages with $\beta$-glucans from oats or barley: a randomized dose-controlled trial. Eur J Clin Nutr. 2005;59(11):1272-1281.

19. Keogh GF, Cooper G, Mulvey TB, et al. Randomized controlled crossover study of the effect of a highly $\beta$-glucan-enriched barley on cardiovascular disease risk factors in mildly hypercholesterolemic men. Am J Clin Nutr. 2003;78(4):711-718.

20. Lupton JR, Robinson MC, Morin JL. Cholesterol-lowering effect of barley bran flour and oil. J Am Diet Assoc. 1994;94(1):65-70.

21. McIntosh GH, Whyte J, McArthur R, Nestel PJ. Barley and wheat foods: influence on plasma cholesterol concentrations in hypercholesterolelmic men. Am J Clin Nutr. 1991;53(5):1205-1209.

22. Li J, Kaneko T, Qin L, Wang J, Wang Y. Effects of barley intake on glucose tolerance, lipid metabolism, and bowel function in women. Nutrition. 2003;19(11):926-929.

23. Narain JP, Shukla K, Bijlani RL, et al. Metabolic responses to a fourweek barley supplement. Int J Food Sci Nutr. 1992;43(1):41-46.

24. Behall KM, Scholfield DJ, Hallfrisch J. Whole-grain diets reduce blood pressure in mildly hypercholesterolemic men and women. J Am Diet Assoc. 2006;106(9):1445-1449.

25. Behall KM, Scholfield DJ, Hallfrisch J. Diets containing barley significantly reduce lipids in mildly hypercholesterolemic men and women. Am J Clin Nutr. 2004;80(5):1185-1193.

26. Pick M, Hawrysh Z, Gee M, Toth E. Barley bread products improve glycemic control of Type 2 subjects. Int J Food Sci Nutr. 1998;49(1):71-78.

27. Behall KM, Scholfield DJ, Hallfrisch J. Lipids significantly reduced by diets containing barley in moderately hypercholesterolemic men. J Am Coll Nutr. 2004;23(1):55-62. 
28. Zhang J-X, Lundin $E$, Andersson $H$, et al. Brewer's spent grain, serum lipids and fecal sterol excretion in human subjects with ileostomies. J Nutr. 1991;121(6):778-784.

29. Ikegami S, Tomita M, Honda S, et al. Effect of boiled barley-ricefeeding in hypercholesterolemic and normolipemic subjects. Plant Foods Hum Nutr. 1996;49(4):317-328.

30. Dersimonian R, Laird N. Meta-analysis in clinical trials. Control Clin Trials. 1986;7(3):177-188.

31. Follmann D, Elliott P, Suh I, Cutler J. Variance imputation for overviews of clinical trials with continuous response. J Clin Epidemiol. 1992;45(7):769-773.

32. Duval S, Tweedie R. Trim and fill: a simple funnel-plot-based method of testing and adjusting for publication bias in meta-analysis. Biometrics. 2000;56(2):455-463.

33. Mantel N, Haenszel W. Statistical aspects of the analysis of data from retrospective studies of disease. J Natl Cancer Inst. 1959;22(4):719-748.
34. Grundy SM, Cleeman JI, Merz CN, et al. Implications of recent clinical trials for the National Cholesterol Education Program Adult Treatment Panel III guidelines. Circulation. 2004;110(6):227-239.

35. Brown L, Rosner B, Willett WW, Sacks FM. Cholesterol-lowering effects of dietary fiber: a meta-analysis. Am J Clin Nutr. 1999; $69(1): 30-42$.

36. Higgins JPT, Green S, eds. Cochrane Handbook for Systematic Reviews of Interventions 4.2.6 [updated September 2006]. In: The Cochrane Library, Issue 4, 2006. Chichester, UK: John Wiley \& Sons, Ltd

37. Food and Drug Administration. Food labeling: health claims; soluble fibre from whole oats and risk of coronary heart disease. Fed Regist [online] 1997;62:15343-15344. http://www.cfsan.fda. gov/ Ird/fr90331.html. Accessed Feb 26, 2008.

38. Talk Paper FDA. FDA allows whole barley foods to make health claim on reducing the risk of heart disease. http://www.fda.gov/ bbs/topics/NEWS/2006/NEW01375.html. Accessed Feb 26, 2008 